\title{
PARTIES, CONSTITUTIONAL \\ ENGINEERING AND \\ GOVERNANCE IN THE \\ SOLOMON ISLANDS
}

\section{Tarcisius Tara Kabutaulaka}

IN LATE JUNE 2004, the then Opposition Leader in the Solomon Islands National Parliament, John Martin Garo, announced that he was 'crossing the floor' to join the Government. ${ }^{1}$ About a week later, on July 8, Garo was sworn in as Minister of State assisting the Prime Minister and took his oath of allegiance to a government he had spent the past year opposing. ${ }^{2}$

In many other parliamentary democracies, the defection of the Leader of the Opposition to the Government side, and his immediate appointment as Cabinet Minister, would have attracted widespread political debate. This was not the case in the Solomon Islands, where the incident passed with just murmurings from a few disgruntled politicians and citizens. Ironically, the most profound expressions of concern most of them not publicly expressed - came from government backbenchers who were not keen on having a former Opposition Leader taking up a Cabinet position that they would have wanted for themselves. ${ }^{3}$ For the rest of Parliament and the country, however, the Opposition Leader's defection was 'politiks nomoa ia' (just politics). Not long afterwards, a new Leader of the Opposition, former Prime Minister Francis Billy Hilly, was elected and parliamentary business continued largely as usual.

The Opposition Leader's defection did not raise many eyebrows in the Solomon Islands because most Solomon Islanders are familiar with tactics like this. The previous Leader of the Opposition, Patteson Oti, also resigned as Opposition Leader and leader of the Solomon Islands Alliance for Change (SIAC) Party in May 2003 and later joined the People's Alliance Party (PAP) — the leading party in the ruling coalition. He was appointed 
Minister for Communication, Aviation and Meteorology. ${ }^{4}$ Garo was, therefore, simply following his predecessor's footprints across the floor of Parliament. This raises a number of points. First, these events illustrate the porous nature of the boundary between the Opposition and Government, and the fact that Solomon Islands politicians, generally, have weak loyalty to parties. Second, it demonstrates the weakness of the country's party system. This is what Jeffrey Steeves referred to as an 'unbounded' political process in which parties 'are not sufficiently strong in binding the loyalty of elected members to ensure that the party controls their legislative behaviour'. 5 Consequently, political allegiances change regularly and political instability is endemic, making it difficult to make and implement medium- and long-term policy and program plans. Because coalition governments are usually fragile, time and effort are spent building and sustaining clientelistic relationships to ensure the maintenance of power. This affects democratic efficiency and the effectiveness of governments.

To avert political instability and enhance democratic efficiency, it is often suggested that countries such as the Solomon Islands need to politically engineer the development of parties by instituting statutory mechanisms that would regulate their formation and operation. Such political engineering, it is envisaged, could also transform the behaviour of politicians and voters and create organised and broad-based parties that are effective in structuring issues and aggregating and representing diverse interests. Further, it is argued that political engineering could also make citizens more aware of the role of parties in the political process.

This chapter discusses how political engineering could strengthen parties and their participation in the promotion of representative democracy in the Solomon Islands. It examines, in particular, how the introduction of statutory mechanisms might affect not only party developments but also governance processes and outcomes overall. First, the chapter provides a brief history of the development of parties in the Solomon Islands and how they have influenced the country's political landscape and its governance processes and outcomes. Second, it provides an overview of the experiences of some countries in the Asia-Pacific. Third, it discusses some of the lessons that Solomon Islands could learn from countries that have attempted to politically engineer the development of parties, and some of the issues that need to be considered when introducing statutory mechanisms to regulate political parties in the Solomon Islands.

I agree that there is a need to politically engineer the development of parties in the Solomon Islands. But, in establishing institutional means to strengthen parties and enhance their participation in the political process, it is also important to note that institutional changes from above will not, by themselves, lead to political stability and effective and efficient governance. Rather, there is also a need to link institutional changes at the top to changes in political culture on the ground, and an enhancement of the masses' understanding of the democratic process and the role that parties play in it. This is important because Solomon Island politicians are influenced not only by the statutes that regulate parties, but by the local political cultures and the demands that constituents place on them. Such societal changes will require mass education that depends on the improvement of the standard and accessibility of education and the development of mass-media communications. 


\section{Parties and governance in the Solomon Islands}

Like other new democracies, Solomon Islands political parties are relatively new, and tend to be small, organisationally thin, elite-based, highly personalised, and have few (if any) institutional or ideological links to the electorate. Many parties are formed, or become active, only before elections. After elections, most parties become quiescent or disappear completely from the public arena. They function largely as institutions for recruiting candidates for elections and for lobbying support for the formation of coalition governments and maintaining power, and only second as vehicles for the electoral mobilisation of the masses, or for structuring issues, aggregating, representing and articulating diverse interests, and translating diverse public views into coherent public policies, for waging election campaigns, forming and maintaining stable governments, and implementing policies. Many politicians, in fact, declare their membership to a party after rather than before elections.

There are a number of factors that influence the nature and development of parties in the Solomon Islands and their participation in the political process. First, (as stated above) parties are relatively new in the Solomon Islands and are still in their early evolutionary stage. The first 'political party' — or, what closely resembled one — was formed as recently as 1965 . This development was associated with the Solomon Islands' political transformations to self-government, the introduction of elections and the inclusion of indigenous Solomon Islanders in the political process. Sam Alasia provides an elaborate account of the historical development of parties and how the introduction of elections and the involvement of Solomon Islanders led to the emergence of parties. ${ }^{6}$ In 1960 , the Legislative Council was established to replace the former Advisory Council that had been set up to advise the High Commissioner, who was the British colonial representative in the country. The Legislative Council consisted of 21 members, six of whom were indigenous Solomon Islanders. Two of the Solomon Islanders were included in the eight-member Executive Council. This was the first time that Solomon Islanders participated in the Colonial Government as policy-makers. In 1964, the first direct election was introduced in Honiara to select a representative for the Legislative Council. Eric Lawson, an expatriate, emerged as winner, and, in early 1965, in an attempt to lobby support to form a government (the Executive), Lawson and the member for North Malaita, Mariano Kelesi, formed the Democratic Party (DP). The party revolved around Lawson and Kelesi, did not have a formal institutional set up and relevance beyond the Legislative Council and was used primarily as an attempt to lobby for support in forming a government. After the election of the Executive, the party ceased to exist because the purpose for which it was set up had been achieved.

After the 1967 election, however, Bill Ramsay, the man who replaced Lawson as Member for Honiara, teamed up with David Kausimae, the Member for South Malaita, and formed the Solomon Islands United National Party (SIUNP). Again, the function of the party was primarily to lobby support for the formation of government. It was not formally registered — because there were no statutory requirements for it to do so and, like the previous Democratic Party, it had no organisational structure beyond the Legislative Council. 
In 1973, the structure of government was further transformed when the High Commissioner became Governor with only nominal power. The Executive power was given to the newly established position of Chief Minister. In preparation for the 1973 general elections, two parties were formed: the People's Progressive Party (PPP), led by Solomon Mamaloni, and the United Solomon Islands Party (USIPA), led by Benedict Kinika. After that election, no party had a clear majority and the two new parties had to lobby for support from the independent members, led by Willie Betu, to form a coalition government. Mamaloni was subsequently elected the country's first Chief Minister, leading a coalition government that consisted of the PPP and some independent members.

In January 1976, the Solomon Islands achieved self-government and in July that year the last election of the colonial era was held. The two parties - PP and USIPA had disintegrated before the election and their members stood as independents. A new party emerged when a recent graduate from the University of PNG (UPNG), and Union leader, Bartholomew Ulufa'alu, formed the National Democratic Party (NADEPA). The new party won eight of the 38 seats in the House and was able to act as the parliamentary powerbroker. On July 14, 1976, Peter Kenilorea, then a relative newcomer to politics, was elected as Chief Minister and led the country to independence. Ulufa'alu became the Leader of Opposition, with his NADEPA members and some independents. ${ }^{7}$

Independent Members of Parliament have played crucial roles in Solomon Islands politics. In most instances, they have held the balance of power in coalition governments, and have, in some cases, caused the collapse of governments by withdrawing their support. Independent members provide an interesting insight into the nature of Solomon Islands (and Melanesian) politics where allegiance is given to individuals rather than to parties. These independent members are attracted to and support individuals (big men) whom they see as having the potential to assert their interests and those of their constituents. They could withdraw their support when they see that another big man could promote their interests much better. In preparation for the 1980 general elections, for example, the Kausimae-led USIPA merged with the Mamaloni-led PPP and formed the new PAP. Kenilorea formed the Solomon Islands United Party (SIUP). The SIUP won 16 seats, the PAP 10, NADEPA two, and the independents 10. The independents and NADEPA held the balance of power and a coalition was inevitable. The SIUP attracted some independent members and formed the Government, and Kenilorea was subsequently elected as Prime Minister. To strengthen the Coalition, the leader of the independents, Francis Billy Hilly, was selected as Deputy Prime Minister. Mamaloni became Leader of the Opposition. ${ }^{8}$

In these situations, the ability to form coalitions depends on the individual big man, rather than on party policies or ideologies. ${ }^{9}$ In this case, Kenilorea was perceived as a much better choice, however, Kenilorea’s Government did not stay in power for long. In August 1981, after only 14 months, the Coalition collapsed. Differences between leaders saw the withdrawal of the independents' support. They realigned themselves with the Opposition and Mamaloni took over as Prime Minister, forming a government that consisted of the PAP, NADEPA and the independents. They stayed in power from 1981 to 1984 . 
Second, Solomon Islands political parties are largely elite-based. Bartholomew Ulufa'alu, a former Prime Minister and veteran Solomon Islands politician, says that, ' $\mathrm{t}$ ] he parties were divorced from the masses. The Solomon Islands elites were then [in the early days of party development] paying more attention to trying to unseat their colleagues, and looked for support upwards towards the colonial administration, rather than outwards to the people. ${ }^{10}$ Parties have not found a way to connect with the people. This is partly because the parties are Honiara-based and oriented to middle-class Solomon Islanders who live and work in Honiara. They do not have organisational links or branches outside of the capital.

Third, the absence of mass media communications makes it difficult to mobilise rural constituents. The print media consists of only one daily newspaper (Solomon Star) and one weekly newspaper (Solomons Express), which are circulated primarily in Honiara and provincial towns such as Auki, Gizo, Lata and Buala. There is only one radio station - the Solomon Islands Broadcasting Corporation (SIBC) — that broadcasts nationwide. Apart from this there are three FM radio stations that broadcast only in Honiara. There is no local TV, although the Telekom relays the British Broadcasting Corporation (BBC) and the Australian Broadcasting Corporation (ABC) TV programs to Honiara residences. Communications and transportation are also made difficult by the dispersed nature of the country's geography.

Parties' abilities to reach the population are also limited by the fact that most do not have the financial (and other) resources to undertake public relations campaigns. After the 1980 general elections, NADEPA attempted to expand its power base beyond the union movement to the rural areas by campaigning nationwide. Its popularity, however, was affected by widespread misconceptions that it was a 'communist' party, ${ }^{11}$ and its ability to reach out was limited by the lack of resources and the absence of a decentralised organisational structure.

From the mid-1980s onwards, many small, thinly organized and highly personalised parties emerged. These affected the ability of parties to establish support among the masses. Just before the 1984 election, for example, a new party, the Solomone Ago Sagefenua (SAS), was formed, increasing the number of parties competing in the election to four: United Party (UP), PAP, NADEPA, SAS and the independents.

In the 1989 general elections, the number of parties participating in the elections further increased to six: PAP, UP, SAS, NADEPA (which had changed its name to the Liberal Party), plus two new parties - the Nationalist Front for Progress (NFP), led by Andrew Nori, and the Labor Party, led by Joses Tuhanuku.

Most of these parties revolve around particular individuals, rather than certain political ideologies. The UP, for example, was organised around Kenilorea, while PAP was organised around Mamaloni, NADEPA around Ulufa'alu, NFP around Nori, and the Labor Party around Joses Tuhanuku. There was no attempt to establish organisational structures that would detach the parties from these individuals.

The 1989 election saw for the first time the emergence of one party, PAP, as the winner of the majority of seats in Parliament. The party's parliamentary leader, Mamaloni, was subsequently elected as Prime Minister. Steeves attributes this to voter' choice: 'Solomon Islands voters opted for dramatic change, selecting the PAP partly on 
the basis of its emphasis of its established leadership, including former PM Solomon Mamaloni. ${ }^{\prime 2}$ I think, however, that PAP's emergence as the majority party had little to do with voters' choice. Rather, it was more to do with the ability of the PAP leadership to persuade elected Members of Parliament to join the party. Many of those who joined did not have party affiliations during the election and only declared their membership to PAP after. It was, therefore, a result of the political ingenuity of PAP leaders more than the ability of the party to persuade voters. Yet, PAP's parliamentary dominance was only short-lived: in October 1990, barely a year into its term in office, the party's hold on government disintegrated during a no-confidence motion before the party's national executive, seeking Mamaloni's removal as PAP's parliamentary leader. For the first time, a party showed enough internal organisation to challenge its own parliamentary leader. Mamaloni was being challenged from within his own party rather than on the floor of Parliament. Steeves describes what happened:

The bonds of party unity, loyalty, and discipline were fractured for all to see. In a dramatic and bold stroke, Mamaloni headed off the challenge by resigning from the party and, using his power as prime minister, forming a 'Government of National Unity and Reconciliation' (GNUR). Mamaloni displaced five members from his cabinet including Deputy Prime Minister, Danny Philip, to make room in the ministerial ranks to build a new governing coalition. ${ }^{13}$

In the 1993 election, the number of parties that competed increased to eight: the PAP, GNUR, UP, NFP, National Action Party of Solomon Islands (NAPSI), the Liberal Party (formerly NADEPA), the Christian Leadership and Fellowship Group, and the Solomon Islands Labor Party. The number of independent members was still significant and, after the election, an independent, Francis Billy Hilly, was elected as Prime Minister, leading a fragile collection of parties that formed the Coalition Government, referred to as the National Coalition Partnership (NCP) Government. By the beginning of October 1994, however, six Members of Parliament, including five ministers, had left the NCP Government. In an attempt to stay in power while lobbying for support, and because of fears that he might be voted out in a motion of no confidence, Hilly did not convene Parliament. In October 1994, however, the then Governor-General, Moses Pitakaka, convinced that Hilly no longer had the majority to rule, sacked him. In November 1994, Parliament convened and elected Mamaloni as Prime Minister. ${ }^{14}$

The 1997 elections saw Ulufa'alu elected Prime Minister on August 27, leading a coalition that called itself the Solomon Islands Alliance for Change (SIAC) Government. Ulufa'alu's Government was shaken in mid-1998 with the defection of six MPs to the Opposition after the dismissal of the Minister of Finance, Manasseh Sogavare, in July. For the next two months, the Opposition, which now claimed to have a majority, pushed for the convening of a special parliamentary session in order to introduce a vote of no confidence in Ulufa'alu's Government. The vote on September 18, 1998, resulted in a tie, which, under parliamentary standing orders, meant that the motion was defeated and Ulufa'alu narrowly survived. His SIAC Government's term in office was, however, shortlived, and he was ousted in a coup in 2000 after civil unrest on Guadalcanal. 


\section{Party fluidity}

Parties in the Solomon Islands are very fluid and lack the organisational structures needed to establish mass support and maintain stable governments. Steeves provides an elaborate discussion of how the fluidity of parties has affected the nature of governance in the Solomon Islands. Since independence, the country has predominantly had (except for a brief period after the 1989 election) coalition governments that are generally unstable. Politicians, because of their general lack of allegiance to political parties, tend to move from one party to another causing an unstable political situation. Nearly every government since independence has not served its full term in office, having been voted out in motions of no confidence, or realignments causing a Prime Minister to alter his political affiliations in order to continue in office. As discussed above, a case in point is when, in 1990, after the resignation of his ministers, Mamaloni resigned from his PAP, pulled in members from other political parties and continued as Prime Minister leading the GNUR. ${ }^{15}$

This is what Steeves referred to as 'unbounded politics'. As a result, there is no cohesion of the Cabinet or government regarding consensus, and little interest in policymaking. This is because, in most cases, coalition governments are formed, posing problems in agreeing on policy within the Cabinet and insecure parliamentary majorities have made it difficult to steer legislation through the Legislature.

But, politicians' political behaviour and the nature of their alliance to parties are also influenced by the national and local political culture. Politicians are motivated predominantly by local issues and the enhancement of cliental relationships that might have little to do with parties and party policies. Much of what influences national politics — including party politics — in the Solomon Islands are often local and parochial issues. As Steeves notes, 'elected members have to cultivate their community bases of support very carefully, ${ }^{16}$ because they depend on that to get into and stay in Parliament. To gain community support, a Member of Parliament does not necessarily have to join a party. Rather, he simply needs to build cliental relationships with big men in his constituency and be perceived to be serving the community's interests.

The country's ethnic and cultural diversity and lack of developed mass media compound the problem further, making it difficult to develop common ideologies that would sustain parties with a large popular base. This could, however, change as citizens identify more with a common nationality and parties become more organised and are able to use the mass media to construct and disseminate common ideologies, or at least, inform electorates about how they would address issues of common concern.

Because parties are organisationally thin, and because candidates are influenced largely by local (rather than national) issues, governments will continue to be built on coalitions rather than single parties. While this might be perceived as a drawback for the political stability necessary to implement development programs, ${ }^{17}$ it has also ensured that no party or individual has become hegemonic or has monopolised power enough to use the State to enhance particular interests and suppress others. This, however, also means that effective and efficient governance is compromised because politicians are often preoccupied with trying to stay in power, rather than with governing. 


\section{Engineering party developments in the Solomon Islands}

To alleviate the problems of political instability (as discussed above) and improve the effectiveness and efficiency of governments, the Solomon Islands could follow the examples of other countries and politically engineer the development of parties. This could be done by providing statutory mechanisms that would ensure that parties take root, are mass based, have loyal membership and play a better role in structuring issues, aggregating and representing diverse interests and translating diverse public views into coherent public policies.

At present, the Solomon Islands has no statutory mechanism for the establishment, operation and development of parties. The country's national Constitution makes only brief reference to parties, under the provision on the protection of freedom of assembly and association. It states that

Except with his own consent, no person shall be hindered in the enjoyment of his freedom of assembly and association, that is to say, his right to assemble freely and associate with other persons and in particular to form or belong to political parties or to form or belong to trade unions or other associations for the protection of his interests. ${ }^{18}$

While this provides for the freedom to form or belong to parties, it does not provide for the operation and development of parties. Nor does it dictate how parties should participate in the political process. Further, there are no statutory mechanisms that address specific issues such as the definition of political parties (what constitutes a political party?), what qualifies them to register as parties, how members should be disciplined if they change party allegiance after being elected, how parties should participate in the electoral process, how to ensure that there is a shift from elite-based to mass-based parties, and how to strengthen the internal organisation of parties.

Those parties that have been registered are incorporated as charitable trusts under the Charitable Trusts Act (Cap. 55). While this enables them to exist and operate as legal entities, it does not provide the kinds of guidelines as outlined above. Parties, therefore, continue to exist and operate in largely the same undisciplined manner as they have since they first came into being in the late 1960s.

The suggestion for the establishment of statutory mechanisms to regulate parties is not new in the Solomon Islands. Many politicians and citizens have expressed similar ideas, although none has provided an elaborate outline of the kinds of political and institutional framework that should be put in place. The Prime Minister, Allan Kemakeza, for example, said that unless there was legislation to prohibit Members of Parliament from switching political alliances, the Solomon Islands would continue to be politically unstable. ${ }^{19}$ Kemakeza, however, did not elaborate on what exactly such a piece of legislation would address. It is here that the Solomon Islands could consider, draw on and learn from the experiences of other countries in the Asia-Pacific region, as outlined by Ben Reilly. The Solomon Islands could introduce statutory mechanisms similar to those that Fiji, PNG, Thailand and Indonesia have done in an attempt to create stable, effective and efficient governments. 
In politically engineering the development of parties, there are a number of issues that need to be considered. First, while statutory mechanisms for prohibiting 'partyhopping' and regulating party developments within Parliament might produce relatively stable parties, it would not necessarily address the fragility of coalition governments that dominate Solomon Islands' political landscape. PNG, for example, having introduced the Organic Law on the Integrity of Political Parties and Candidates (OLIPPC), now has to come to terms with the fragility of coalition governments. This is complicated by the existence of independent Members of Parliament who have no party affiliations and can join a coalition to serve particular interests. In the Solomon Islands (as in PNG), independent members have, in the past, contributed to the instability of coalition governments by shifting their support from one group to another. While the rights of Members of Parliament to represent their constituencies in any way they want is recognised, this is an issue the Solomon Islands must address in any political engineering endeavour. As PNG scholar Henry Okole states,

there is now ground to fear that Independent candidacy would be greatly abused in the next general election. Something needs to be done before 2007 to address this constitutional right with a view of protecting it. But, at the same time, the integrity of Parliament should not be compromised by free-floating MPs with devious tactics. Independents can unnecessarily sink or change a coalition formation by altering numbers on both sides of Parliament. ${ }^{20}$

Hence, any institutional or political engineering of parties must address the stability of coalitions. Nearly every Solomon Islands government since independence - except for a brief period of PAP rule after the 1989 elections — has been based on coalitions. This is likely to continue given the unlikelihood of a single party gaining power through elections. It is, therefore, pertinent that discussions of party development must also involve discussion about how to strengthen coalitions.

Second, in discussing the engineering of party developments in the Solomon Islands, it is important to note that while prohibiting elected members from 'partyhopping' might positively influence the political behaviour of individual members, it would not necessarily change the internal organisation of parties. How parties are institutionally organised is vital to their development and their ability to attract and maintain mass support as well as the ability to capture and manage power. All the parties in the Solomon Islands, as mentioned above, are thinly organised and often have only nominal existence outside Parliament. The only exception is the PAP, which is the only party that has consciously maintained an organisational structure outside Parliament. Its relative success in the 2001 election (and in leading the current coalition) was attributable to its institutional development.

In Indonesia, Thailand and PNG, there are statutory regulations that require parties to demonstrate a certain level of institutional development before they can participate in elections. In PNG, for example, parties are required to lodge an application for registration to the Registry of Political Parties, the body that approves the registration of parties. This is part of an attempt to force parties to develop institutional structures and to reduce the number of parties. 
Fiji, despite changes to the electoral system, does not have such a regulation and this has led to the mushrooming of many small and thinly organised parties that have little (if any) capacity of attracting mass-based support, and gaining and maintaining political power. Even parties such as the Alliance and NFP, which formerly had mass support among indigenous and Indo-Fijian voters respectively, virtually disintegrated in the late 1990s. The Fiji Labour Party has also broken up into two parties: the Fiji Labour Party and the New Labour Unity Party (NLUP), led by Tupeni Baba. This is partly because the 1997 Constitution, while addressing the stability of parties within Parliament, does not dictate how parties are organised and registered outside Parliament.

The Solomon Islands, therefore, might consider putting in place regulatory frameworks that guide the institutional development of parties. This could prevent the mushrooming of many small and thinly organised parties at election times.

Third, parties could also be strengthened through electoral reforms. A form of alternative voting system could be adopted to help strengthen the presence of parties in different parts of the country and force voters to vote along party lines. Fiji's case shows, however, that such changes in the electoral system do not always produce the desired outcome.

Fourth, in attempting to engineer the development of parties, it must be noted that such development and the effective and efficient participation of parties in the governance process cannot be addressed simply by changing statutory frameworks from above. While that is important, we must also note that parties are influenced by the political cultures of the societies in which they operate. Voters' perceptions of the role of parties and the nature of their relationship to Members of Parliament also influence how parties are organised and how politicians relate to parties. Okole notes that in PNG (as in the Solomon Islands) citizens often view the State as a bottomless reservoir of resources and Members of Parliament as 'literal deliverers of anything and at any cost'. This, in turn, dictates how Members of Parliament relate to and use their parties. Similarly, Standish, in discussing the introduction of OLIPPC in PNG, states, 'Observers and advisers on these remain sceptical of political engineering, the notion that the country's entrenched political culture of localized and personalized campaigning and fluid party allegiances can be changed from above - in effect, by constitutional fiat. ${ }^{21}$ Ron May, a senior ANU academic, also states that in PNG clan-based voting will not be easily changed by political engineering at the top. ${ }^{22}$

For parties to function well there is a need to educate citizens about the role of parties and their importance in representative democracy. The development of parties, therefore, depends not only on changes in the party structures, but on parallel improvement in citizens' awareness about parties. As Okole notes, in respect to PNG, there is a need for transformation among the electorates and parliamentary members. This is a long-term issue that will depend on the improvement of the country's formal education system, as well as development in institutions such as mass-media communications. As stated above, the Solomon Islands media is still underdeveloped, making it difficult for parties to reach out to the population. The development of parties in the Solomon Islands will go hand-in-hand with the development of the mass media. This is vital, not 
only for the purposes of campaigning, but in educating the public (and hopefully changing political culture).

\section{Civil unrest, federalism and political parties}

There are two recent events in the Solomon Islands that have important implications for the development of parties. The first was the civil unrest that started on the island of Guadalcanal in late 1998 and resulted in an Australian-led Pacific Islands Forum regional intervention force called the Regional Assistance Mission to Solomon Islands (RAMSI). ${ }^{23}$ The civil unrest was described widely by the media and international commentators as an 'ethnic conflict' between the peoples of Malaita and Guadalcanal, because much of the overt violence was between some people from these two islands.

It is interesting, however, that despite the ethnic nature of the conflict, political parties did not become ethnically based. This is unlike the case of Fiji, where parties are generally ethnic-based. It was this (plus the coups of 1987) that led to the introduction of statutory changes, such as the 1997 constitutional reform, that aimed to facilitate the development of multi-party governments. Despite this, parties continued to be founded, and draw support from, the two major ethnic groups — the indigenous Fijian and IndoFijian.

In the Solomon Islands, however, the civil unrest did not engender the development of ethnic- or island- or provincial-based parties. Instead, many of the parties continued to revolve around individual big men or Members of Parliament. Parties such as the PAP, which have established formal structures, continue to maintain a multi-ethnic and multi-provincial base.

There are a number of reasons for this. First, the country's enormous ethnic and linguistic diversity ${ }^{24}$ makes it difficult for any particular island or ethnic group to capture and maintain political power. Unlike Fiji, where there are two major ethnic groups that can be mobilised to compete for political control, Solomon Islands' ethnic heterogeneity makes it difficult for one or two groups to become dominant.

Second, the civil unrest was primarily between some Guadalcanal and Malaita people, and any parties that are based in these two provinces would not have been able to capture power because collectively they have only 22 Members of Parliament - 14 for Malaita and eight for Guadalcanal — in a 50-member House. Hence, individually, they would not have the numbers to capture power, and it is unlikely that provincial-based parties would be able to attract support from other provinces.

Third, despite the seemingly ethnic nature of the civil unrest, there was widespread recognition, at the community and national parliamentary levels, that the causes of the civil unrest lay in broader socioeconomic and political issues that transcended provincial and ethnic interests. Hence, it could be addressed through collective bipartisan efforts. This is not to say that partisan provincial interests could not be articulated. Of course they could, and this is manifested in the development of social movements such as the Malaita Ma'asina Forum, formed in 2004 with the objective of mobilising Malaitans to develop their province. It is, however, unlikely that such social movements will develop into parties that attempt to capture political power at the national level. This is especially 
so if the proposed Constitution is adopted. This is because the proposed Federal Constitution states that 'A political party is not eligible for registration if that party is founded purely on religious, linguistic, racial, ethnic, corporatist basis or seeks to engage in propaganda based on those matters. ${ }^{25}$

Fourth, because parliamentarians tend to gravitate around individuals rather than parties and their policies, it is likely that they will form and maintain parties around individuals rather than ethnic or provincial groups. With individuals, politicians have the freedom to move around and take advantage of the power play more than they would under a provincial-based party.

Although individually each of the above reasons might not have been sufficient to prevent the formation of ethnic or provincial-based parties, collectively they made such parties less attractive as vehicles for capturing and maintaining political power.

The second issue that has important implications for the development of parties in the Solomon Islands is the proposal to change Solomon Islands' system of government from the current unitary system to a federal system. ${ }^{26}$ Federalism offers a more decentralised system, which raises three important questions: would parties contest federal and state elections? Would federalism see the emergence of state-based parties? If that happens, would that result in political divisions along island and ethnic groups?

The framework for the proposed federal system is provided for in the draft Federal Constitution that is yet to pass through the National Parliament. Unlike the present Constitution, the draft has a specific provision (Chapter Twenty, Part II, Sections 218-23) that addresses political parties in some detail. It provides for, not only the right to form parties, but guidelines on registration and party discipline. A major provision is that 'A member of Parliament who resigns from the political party that sponsored the member's election or leaves the political party to join another or remains in Parliament as an independent loses his or her seat.' This is similar to the provisions of the 1997 Fiji Constitution.

It seems that under a federal system, while there will be parties that will compete at the federal and state levels, there will be others that will be state-based. It is unlikely that one or two parties will become dominant in the way that the Labor and Liberal Parties have been able to do in Australia, or the Democrats and the Republicans in the US. Whether the emergence of state-based parties will lead to disunity is difficult to say. I suspect, however, that because of the increasing economic interdependence of the provinces (or states-to-be), the existence of state-based parties will not necessarily lead to disunity at the national level.

\section{Conclusion}

The development of political parties is vital to advancing stable, effective and efficient government in the Solomon Islands, as well as in other Melanesian countries. Parties play an important role in representative democracy and are central to effective parliamentary governance. This could be done by introducing statutory mechanisms that could regulate the development of party institutions and the nature of their participation in the political process. Several strategies have been employed in the Asia-Pacific region in an attempt to 
engineer the development of parties, and the Solomon Islands could learn from their experiences.

One thing is obvious: statutory reforms (the top-down approach) cannot, by themselves, produce desired changes at the bottom. The introduction of statutory regulations must accompany awareness programs that will inform citizens of the importance of parties and their role in representative democracy. This means that in attempting to engineer the development of parties we must also be aware of the nature of political culture in the Solomon Islands. This will help us understand the factors that influence the behaviour of politicians and voters, who are both important in the success of parties. Any statutory reform must take into consideration the impact of political culture on party institutions.

It is also important to note that parties will take time to develop in the Solomon Islands. Political engineering could establish the frameworks for party developments. It will, however, take many more years for parties to take root and become part of citizens' political psyche. That will depend on the improvement of political education and massmedia communications.

\section{Footnotes}

1 SIBC News, June 29, 2004, available at http://www.sibconline.com.sb (Accessed on November 13, 2004).

2 SIBC News, July 8, 2004, available at http://www.sibconline.com.sb (Accessed on November 2004, 13).

3 SIBC News, July 8, 2004, available at http://www.sibconline.com.sb. SIBC carried this news piece in which the Prime Minister, Allan Kemakeza, denied rumours that there was a rift in his government due to backbenchers' disagreement about the appointment of John Garo.

4 SIBC News, February 12, 2004, available at http://www.sibconline.com.sb (Accessed, November 15, 2004).

5 Steeves, Jeffrey S. 1996. 'Unbounded Politics in the Solomon Islands: Leadership and Party Alignments.' Pacific Studies, Vol. 19, No. 1. pp. 115-38, at p. 117.

6 Alasia, Sam. 1997. 'Party politics and government in Solomon Islands.' State, Society and Governance in Melanesia Project (SSGM) Discussion Paper 97/7. Canberra: RSPAS-ANU. See also Bennett, Judith. 1987. Wealth of the Solomons: A History of a Pacific Archipelago, 1800-1978. Honolulu: University of Hawaii i Press.

7 Ibid.

8 Ibid.

9 Steeves, op. cit.

10 Ulufa'alu, Bartholomew. 1983. 'The Development of Political Parties.' In Peter Larmour and Sue Taura (eds), Solomon Islands Politics, Suva: Institute of Pacific Studies, University of the South Pacific. pp. 101-6.

11 Alasia, op. cit.

12 Steeves, op. cit. p. 117.

13 Ibid. p. 123.

14 Ibid.; and Alasia, op. cit.

15 Ibid. 
16 Steeves, op. cit. p. 132.

17 Ibid.

18 Solomon Islands National Constitution, Section 13 (1).

19 SIBC News, February 9, 2004.

20 Okole, Henry. 2005. 'Dealing with coalition instability'. In The National (Commentary), January 5. Available at http://www.thenational.com.pg/0818/focus1.htm (Accessed on January 17, 2005.)

21 Standish, B. 2002. 'Constitutional Engineering in Papua New Guinea's Problematic Democracy.' Paper presented at the Foundation for Development Co-operation Development Research Symposium: South Pacific Futures, Brisbane, July 22-24. Available at http://www.fdc.org.au/files/standish.pdf (Accessed on October 22, 2004.)

22 ABC Radio Australia, Asia Pacific. 2004. Available at http://www.abc.net.au/asiapacific/specials/png/process.htm (Accessed on October 15, 2004.)

23 See Kabutaulaka, Tarcisius Tara. 2001. 'Beyond Ethnicity: The Political Economy of the Guadalcanal Crisis in Solomon Islands.' SSGM Working Paper 01/1; Moore, Clive. 2004. Happy Isles in Crisis: The historical causes for a failing state in Solomon Islands, 1998-2004. Canberra: Asia Pacific Press; Frankel, Jon. 2004. The Manipulation of Custom: From Uprising to Intervention in the Solomon Islands. Wellington: Victoria University Press.

24 The Solomon Islands has a population of about 500,000 people who speak around 87 different languages. There are also identifications along island and provincial lines.

25 Solomon Islands Government. 2004. Solomon Islands Federal Constitution. Draft.

26 The demand for federalism has a long history that dates back to the time of independence in 1978, although the current proposal emerged as a result of demands made by Guadalcanal Province during the recent civil unrest. It looks likely that the federal system will be introduced soon. A federal Constitution was drafted and will go before Parliament later in 2005. 